\title{
"A ESCADA DA MEMÓRIA": ARTE E SOBREVIVÊNCIA NO COMPLEXO DO ALEMÃO
}

\author{
Adriana Facina ${ }^{1}$
}

\begin{abstract}
Se eu morrer, vá embora com sua mulher e por onde passar pode dizer que Corisco tava mais morto do que vivo. Virgulino morreu de vez e Corisco morreu com ele. Mas por isso mesmo precisava ficar em pé, lutando até o fim, desarrumando o arrumado. Até que o sertão vire mar e o mar vire sertão. (Fala de Corisco no filme Deus e o Diabo na Terra do Sol, 1964) ${ }^{2}$
\end{abstract}

Durante trabalho de campo no Complexo do Alemão ${ }^{3}$, Zona Norte do Rio de Janeiro, acompanhei um episódio que evidenciava um confronto de projetos políticos e estéticos na cidade. Era dia 09 de novembro de 2013, um sábado de sol, quando cheguei ao Morro do Alemão, uma das favelas que formam o Complexo, para participar do festival Circulando - Diálogo e Comunicação na Favela. O Circulando é um dos maiores eventos do Complexo do Alemão e é organizado anualmente, desde 2010, pelo Instituto Raízes em Movimento. Criado em 2001 por moradores do Complexo ${ }^{4}$, o Insituto Raízes em Movimento atua no território em diversas frentes: cultura, memória, qualificação profissional, direitos humanos, meio ambiente, direito à cidade, entre outros. Durante o evento circulam por ali pessoas da favela e de fora dela, crianças, jovens, velhos, artistas, ativistas, professores. As atividades envolvem cinema, debates, poesia, música, dança, teatro, exposições fotográficas, grafite. É um dia de diversão, aprendizados, discussão política e fruição artística. O objetivo, segundo seus

\footnotetext{
${ }^{1}$ Universidade Federal do Rio de Janeiro, Brasil. Email: adriana.facina2@gmail.com ORCID id: https://orcid.org/0000-0001-9381-5134

2 Agradeço a referência a Deus e o Diabo na Terra do Sol a Daniel Silva.

3 A escrita deste artigo foi possibilitada pela concessão de bolsa de produtividade do CNPq, processo 307156/2017-6). Uma versão preliminar do mesmo foi apresentada no 38o Encontro Anual da ANPOCS, no GT Sobre periferias: novos conflitos no espaço público.

4 "Complexo" é um termo frequentemente utilizado pelos moradores do Complexo do Alemão para se referirem ao seu local de moradia. Isso marca uma diferença com as outras favelas, nas quais o termo 'complexo' raramente é usado desse modo. Embora a imprensa, as forças policiais e as autoridades públicas se refiram, além do Alemão, aos Complexos da Penha, Acari, Maré etc, seus moradores não costumam adotar essa nomenclatura. Assim, o termo Complexo, quando referido a um território, significa, entre favelados, Complexo do Alemão.
} 
organizadores, é proporcionar um momento em que o Raízes "presta contas" para a comunidade de suas ações ao longo do ano. ${ }^{5}$

A Avenida Central, palco do Circulando, foi uma das áreas mais afetadas pela intervenção do Programa de Aceleração do Crescimento (PAC) ${ }^{6}$, iniciado em 2007 no Complexo do Alemão. O seu impacto mais dramático foi o das remoções de várias casas e das famílias que nelas moravam. Essas remoções foram justficadas pelo poder público pela construção das estações do teleférico que ligava o bairro de Bonsucesso a diversos pontos do Complexo do Alemão. No caso das remoções da Avenida Central, elas acabaram se mostrando inúteis em sua maioria, pois a obra que implantou a estação Morro do Alemão prescindiu da retirada das casas naquela localidade. Para compreendermos a dimensão do sofrimento que a remoção provoca em moradores de favela é preciso lembrar, com Victor Valla, que "a estratégia de moradia na favela não é uma estratégia pura e simplesmente de habitação, mas sim uma estratégia muito mais ampla de sobrevivência, da qual a moradia é apenas um de seus aspectos." (Valla, 1986: $26)^{7}$.

Dessa maneira, quando uma família é removida, laços sociais que organizam seus modos de vida e que dão sentido à existência são desarticulados. Esta desarticulação atinge desde elementos mais concretos como a proximidade do trabalho

\footnotetext{
${ }^{5}$ Ver: https://wikifavelas.com.br/index.php?title=Instituto Ra\%C3\%ADzes em Movimento

5.Atualmente, o Circulando foi transformado em um programa do Instituto Raízes em Movimento, englobando o evento anual e o favela.doc, braço audiovisual do instituto voltado para a produção de documentários sobre questões locais e para a organização de um cineclube.

6 O Programa de Acelelração do Crescimento foi criado pelo governo federal em 2007, durante o segundo governo de Luís Inácio Lula da Silva, e buscava englobar "um conjunto de medidas destinadas a desonerar e incentivar o investimento privado, aumentar o investimento público e aperfeiçoar a política fiscal, promovendo o crescimento acelerado do país com diminuição das desigualdades de renda e entre regiões, preservando, entretanto, o equilíbrio fiscal e monetário e reduzindo a dívida e a vulnerabilidade externa. No discurso em que anunciou o Programa, o presidente da República fez questão de mencionar que o PAC se ampliaria e desdobraria em várias etapas, mas que inicialmente abarcaria cinco blocos: medidas de investimento em infra-estrutura, inclusive de infra-estrutura social, como habitação, saneamento básico e transporte de massa, além de determinados programas de água e eletricidade, como o Luz para Todos, que representam, de forma direta, melhoria da qualidade de vida da população de baixa renda; medidas de estímulo ao crédito e ao financiamento; medidas de desenvolvimento institucional; medidas de desoneração e administração tributária; e medidas fiscais de longo prazo." (http://www.fgv.br/cpdoc/acervo/dicionarios/verbete-tematico/programa-de-aceleracao-do-crescimentopac)

${ }^{7}$ Com uma postura crítica às remoções e aos planos habitacionais produzidos pelo Estado para as moradias populares, Victor Valla afirma ainda que "A favela não é apenas uma alternativa dos pobres à falta de moradias urbanas. A questão favela não se limita apenas à questão da moradia, suas causas não se limitam ao déficit de moradias urbanas baratas. Esta visão tecnocrática da realidade se restringe a ver o mundo a partir da lógica da classe dominante, desconhecendo que a favela é parte da população favelada, que inclui outras coisas além do não pagamento da moradia, ou seu barateamento acentuado. Nela está incluída questões como: menores despesas com os transportes face à maior proximidade do trabalho; barateamento de serviços através de uma rede informal de ajuda entre os moradores; facilidade de "biscates" pelo de morar perto das regiões mais ricas da cidade etc." (Valla, 1986: 93)
} 
ou a ajuda material recebida de parentes e vizinhos, até outros da ordem da subjetividade e dos afetos. Uma moradora removida relatava certa vez, num encontro promovido pelo Instituto Raízes em Movimento, que sentia muita falta de acordar aos domingos com o cheiro do pão fresquinho invadindo sua casa, pois seu pai, que morava em terreno contíguo ao seu, tinha o hábito de fazer esse "agrado" a ela. Como a casa dela foi a única da família a ser derrubada, ocasionando sua mudança para um condomínio do PAC situado fora da favela, hábitos como esse que marcavam seu vínculo afetivo com familiares foram suspensos. A emoção em sua fala transparecia a perda que não poderia ser compensada com o status de "viver em condomínio como os de classe média", em referência à propaganda que os agentes do PAC faziam para convencer os removidos de que a mudança seria para uma condição de vida melhor. ${ }^{8}$

A memória das remoções, da destruição de casas e, com elas, das histórias de famílias que moravam ali, estão nas ruínas que foram deixadas para trás. Valas negras foram abertas, entulhos de obras inacabadas acumulavam lixos e ratos. Para os que foram removidos, acumulavam-se também dores e sofrimentos. Para quem ficou, acumulavam-se indignação e medo de um futuro incerto. Como dizem alguns moradores: “afinal, quem poderá garantir que não haverá mais remoções?”.

Um dos marcos do PAC na Avenida Central foi a destruição dos muros grafitados que formavam uma galeria a céu aberto, com obras de artistas do Alemão e de outros lugares do país e do mundo. Enquanto os muros grafitados eram derrubados, estações do teleférico que estavam sendo construídas tinham as paredes cobertas pelos grafites do Studio Kobra, de São Paulo. Grandiosos, esses painéis, que retratavam cenas e histórias daquele lugar, foram confeccionados sem que se considerasse a ampla atividade dos artistas do próprio Complexo.

E foi a intensa atividade de grafiteiros daquele sábado que chamou minha atenção. A precariedade material e de direitos faz com que a vida seja sempre improviso, que se esteja sempre pronto a recomeçar do zero. Pensando com Michel de Certeau, podemos dizer que a cultura oscila entre duas formas, a que permanece e a que inventa, seguindo aspectos conjunturais. (Certeau, 1995: 239) E foi o que vi ali. Muitos artistas refazendo o caminho de arte da Avenida Central, decorando casas, colorindo

\footnotetext{
${ }^{8}$ Sobre os conflitos que marcam as mudanças dos moradores das favelas do Complexo do Alemão para os condomínios do PAC, ver a tese de OLIVEIRA, Bruno Coutinho de Souza. "Não tem essa de separação, aqui é tudo Complexo do Alemão!": uma etnografia dos espaços urbanos em um conjunto residencial no Rio de Janeiro. (Tese de doutorado). Universidade do Estado do Rio de Janeiro, Instituto de Estudos Sociais e Políticos, 2018.
} 
muros ou ruínas de muros, ressignificando o território como a dizer: "vocês entram, destróem, removem, mas a gente volta e faz tudo de novo." Invenção e permanência em combinação na luta incessante exigida pela cultura no plural. (Certeau, 1995: 242) Lembrei da música Opinião, composta por Zé Keti em 1964, ano do golpe militar. A música protestava contra as remoções na cidade do Rio de Janeiro no início da década de 1960, quando Carlos Lacerda governava o estado da Guanabara (1960-1965). Ela traz à memória a longa história da luta dos favelados pelo direito à cidade:

\author{
Podem me prender \\ Podem me bater \\ Podem até deixar-me sem comer \\ Que eu não mudo de opinião \\ Daqui do morro \\ Eu não saio não \\ Se não tem água \\ Eu furo um poço \\ Se não tem carne \\ Eu compro um osso \\ E ponho na sopa \\ E deixa andar \\ Fale de mim quem quiser falar \\ Aqui eu não pago aluguel \\ Se eu morrer amanhã, seu doutor \\ Estou pertinho do céu
}

A atualidade da música no Rio de Janeiro do século XXI remete à perenidade desse existir em sobrevivência, que necessita de táticas ${ }^{9}$ e improviso para garantir a vida quando nada está garantido. $\mathrm{O}$ direito à moradia em favelas é sempre precário e instável e as remoções são o símbolo sempre atualizado dessa fragilidade. Porém, se a ameaça é perene, também o é a luta, a teimosia em disputar um território, um modo de vida, um jeito de construir cidade que inclua os marginalizados.

Voltando aos grafites do Circulando, um deles atraiu as atenções de modo especial. Uma escada no meio do caminho levava ao segundo andar de uma casa que

\footnotetext{
${ }^{9}$ Utilizo aqui a noção de tática baseada em Michel de Certeau. Definida por este autor como a "arte do fraco", tática é "a ação calculada que é determinada pela ausência de um próprio. (...) A tática não tem lugar senão o do outro. E por isso deve jogar com o terreno que lhe é imposto tal como o organiza a lei de uma força estranha. (...) Aproveita as 'ocasiões' e delas depende, sem base para estocar benefícios, aumentar a propriedade e prever saídas. O que ela ganha não se conserva. Este não lugar lhe permite sem dúvida mobilidade, mas numa docilidade dos azares do tempo, para captar no voo as possibilidades oferecidas por um instante. Tem que utilizar, vigilante, as falhas que as conjunturas particulares vão abrindo na vigilância do poder proprietário. Aí vai caçar. Cria ali surpresas. Consegue estar onde ninguém espera. É astúcia.” (Certeau, 2012: 94-5)
} 
não existia mais. Deixada ali, espécie de "símbolo do descaso", no dizer de alguns moradores, era também uma afronta e uma ameaça. Bem construída, mostrava um grande investimento de recursos e esforços de uma família removida. Não era uma casa de quem chegou ontem na cidade. Era uma casa construída e melhorada por anos de trabalho de seus moradores. A escada era a prova disso.

Quando cheguei, o artista plástico Mario Bands, morador do bairro da Penha, vizinho ao Complexo, varria aquela escada de modo caprichoso, detalhista, sem deixar nenhum grão de poeira nos degraus. A cena parecia irreal: uma escada sem uso, que não levava a lugar algum, sendo varrida com tanta dedicação. Em seguida, começaram a vir as cores, as formas, os desenhos geométricos, as gotas de tintas escorrendo pelos degraus, dando movimento e beleza ao "símbolo do descaso".

Aos poucos, novos sentidos foram sendo criados para aquela ruína. A performance do artista era um modo de dizer "daqui do morro eu não saio não", tecendo outras memórias, entrelaçando a dor dos que foram removidos, com a invenção de um outro futuro, mais esperançoso. O "símbolo do descaso" foi se transformando num monumento, a "escada da memória", no dizer de alguns moradores que ali estavam assistindo a aquela criação artística em tempo real. Os que passavam riam, fotografavam, se admiravam. Reviviam a casa e homenageavam os que não moravam mais ali, contando suas histórias. Por várias semanas, a escada se tornou um point de visitação e muitas fotografias foram feitas, com as pessoas subindo seus degraus e posando para as lentes, compartilhando essas imagens nas redes sociais. A escada, que antes levava a lugar algum, se abria agora para o céu, amplo de horizontes e de sonhos, parecendo indestrutíveis como as tintas dos grafiteiros do Alemão. Era incrível a alegria que transparecia nas fotos tiradas ali. 


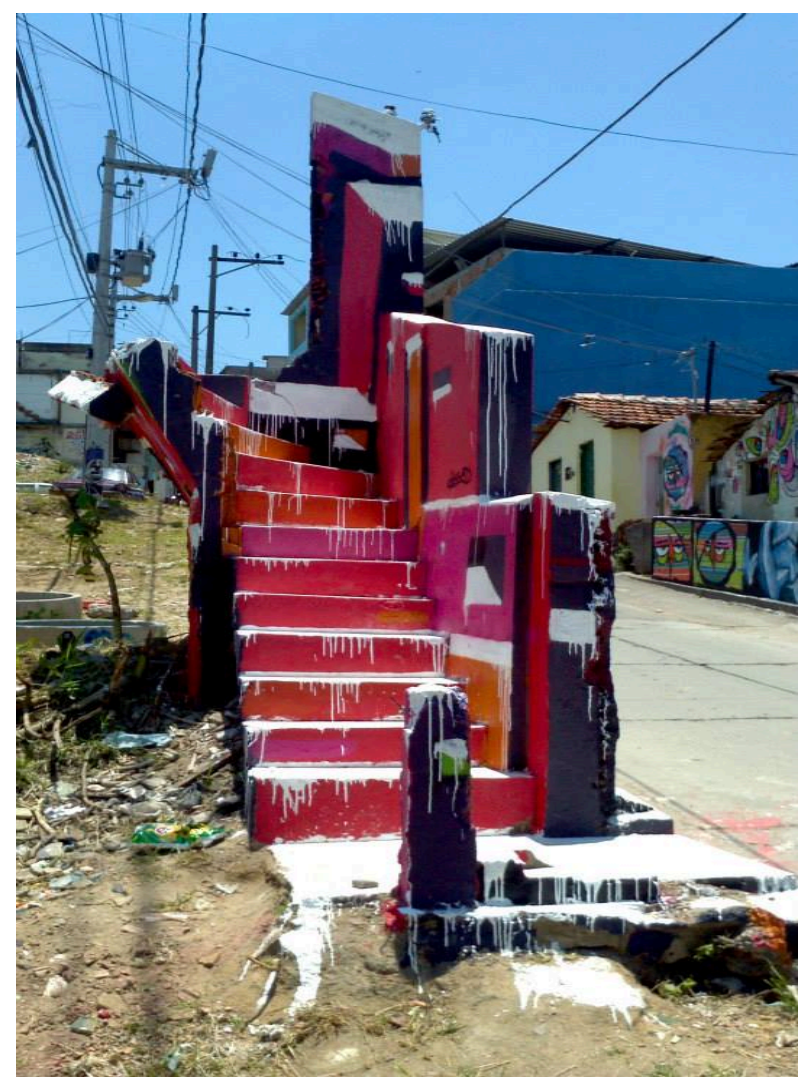

Foto de autoria desconhecida

Pouco tempo depois, no dia 04 de dezembro, acessei a rede social Facebook e descobri por meio de uma postagem de Helcimar Lopes, agente cultural local e então integrante do Instituto Raízes em Movimento, que a escada havia sido destruída. Nos comentários da foto da destruição da escada, postada por Helcimar, algumas falas indignadas de moradores. Listei alguns desses comentários abaixo:

1. Na hora que tinham mesmo que derrubar ninguém o fez. Depois que virou obra de arte passou a incomodar...

2. Eu não acredito nisso como podem depois de tanto tempo q essa arte ficou nesse msm lugar ninguem reclamou e agr vinheram destruir ? fala serio né !

3. caraca isso foi uma sacanagem!! pocha eu tinha comentado com um amigo no sábado que eu achava muito show essa obra de art!!

4. Lembram da Escada?

Sim, aquela escada que depois da maravilhosa obra do PAC (Aquela que mal começou, não serviu pra nada e não foi concluída) ficou conhecida como símbolo do descaso.

Durante o evento Circulando, o grande artista Mario Bands, realizou um belíssimo trabalho de intervenção artística, tornando aquele esqueleto, um monumento.

Mas tudo o que é bom (e bonito) para o povo, incomoda aqueles que não são daqui (e não fazem questão alguma de se importar com a nossa gente) e isso 


\section{foi o que sobrou da Escada.}

Fiquei de verdade emocionada quando vi as fotos que o Helcimar fez... Mas uma vez essa gente tenta calar a nossa voz... Mas, esta ação, (porque não chamar de vandalismo?) mostra como a voz do povo, até aquelas que vem em silêncio, em forma de arte, é capaz de trazer à tona coisas que estavam esquecidas.

Mario Bands, sua arte incomodou e por isso veio ao chão, mas tenha certeza que mais do que nunca está eternizada por todos aqueles que entenderam a proposta do seu trabalho e por cada morador que por ali passava e via aquela que se tornou bela! Avante!!

De modo rápido, os tratores da prefeitura destruíram a escada e retiraram seus escombros, contrastando com com as ruínas das casas removidas, que lá permaneceram por muitos meses. A rapidez das máquinas foi tamanha que Helcimar mal conseguiu guardar pequenos pedaços da escada derrubada para recordação, a pedido de Mario Bands. Em outra ocasião durante o trabalho de campo, uma moradora removida pelo PAC também relatou que havia guardado um pedaço da parede de sua casa que foi derrubada durante as obras do PAC. Esses gestos me lembraram as histórias de refugiados palestinos que guardam há décadas chaves de suas casas derrubadas ou ocupadas. Qual o propósito de se derrubar uma escada que estava há anos naquele local, logo após a intervenção que a transformou em arte e "lugar de memória" 10 reconhecido pelos moradores do território? A tática de terra arrasada, de fato ou simbolicamente, frequentemente integra estratégias de ocupações militares e projetos civilizadores variados. A história assim o demonstra.

Em sua página no Facebook, Helcimar postou uma história da escada em fotos, resumindo o que narrei aqui:

\footnotetext{
${ }^{10}$ Utilizo aqui a expressão "lugar de memória" como categoria nativa, que surgiu nas falas de moradores e mesmo do próprio artista que grafitou a escada, e não no sentido desenvolvido pelo historiador francês Pierre Nora.
} 


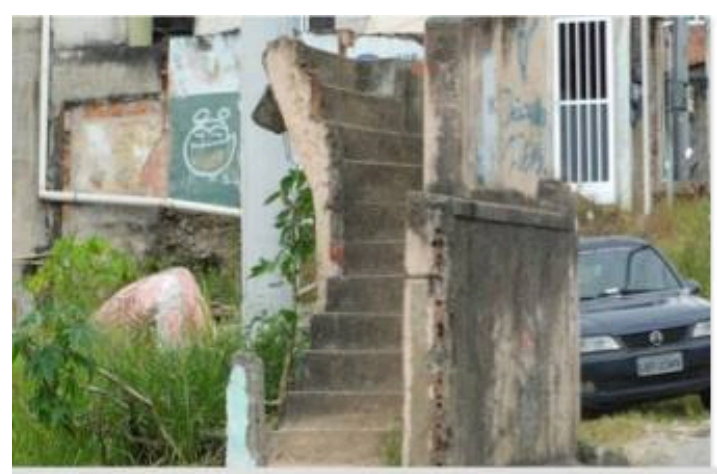

Morro do Alemão - destroço do PAC: um pedaço de casa, lembrando a cada um, e a cada instante, suas perdas.

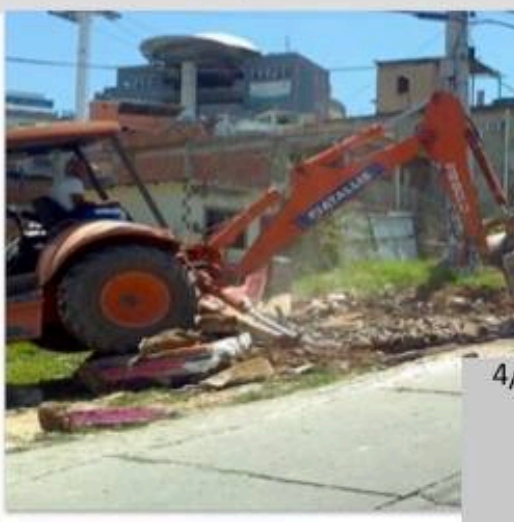

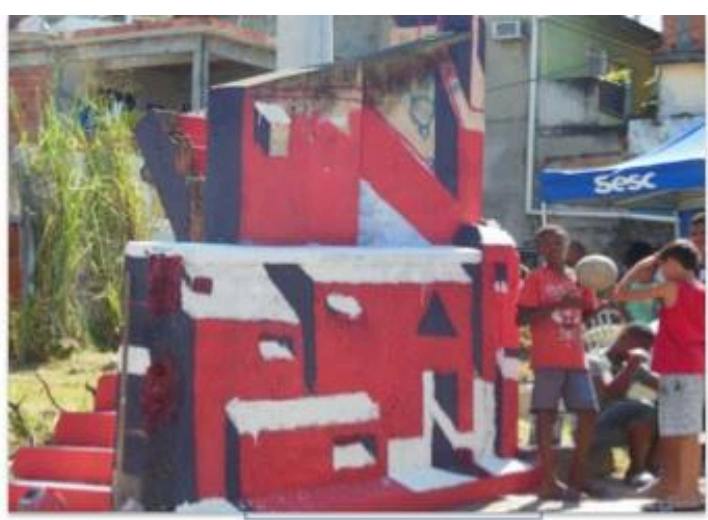

$16 / 11 / 2013$, a intervenção do artista transforma dor e perda em arte, em uma ação de amor e resistência

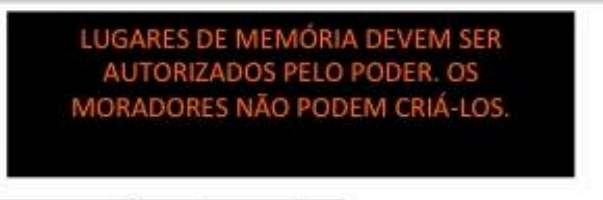

$4 / 12 / 2013$, o trator passa por cima da escada que se tornou um monumento de arte e resistência no Alemão.

Importante notar que a derrubada dos grafites no Complexo do Alemão se deu num contexto de reformas urbanas que preparavam a cidade para a Copa do Mundo de 2014 e para as Olimpíadas de 2016. Nessas intervenções, o grafite foi valorizado pela prefeitura como arte urbana em diversos espaços da cidade, incluindo a realização de murais na orla da Zona Portuária. Mencionamos acima que as estações do teleférico do Alemão contavam com grafites do famoso Studio Kobra. Christina Vital analisou essa valorização do grafite pelo poder público municipal naquela conjuntura de remodelamento da cidade:

Em recente matéria publicada na Revista O Globo de 19 de janeiro de 2014 lia-se "Grafite no poder. Com apoio da prefeitura, dez grupos de artistas vão pintar 40 quilômetros de muros da linha 2 do metrô, na Zona Norte". Em destaque dois grafiteiros famosos na cena carioca, Acme e Airá Ocrespo. Ambos são curadores do projeto que fará intervenção nos muros da Linha 2 do metrô, o GaleRio, da prefeitura do Rio de Janeiro. O projeto é dirigido pelo "Instituto Eixo Rio, autarquia recém-criada pelo poder municipal com o objetivo de ampliar o diálogo com a Zona Norte", cujo presidente é o rapper Marcelo Deghettu. Sobre o que poderia ser visto como cooptação do grafite ele diz: “A intensão não é encaretar. É fortalecer, profissionalizar. Sempre pergunto: 'Vocês querem ser uma linha na planilha ou os donos da planilha'? Essa rapaziada tem ideia de rua, mas não de ar condicionado. Tem que materializar isso". Já Airá Ocrespo revelou ter tido uma relação conflituosa 
com a proximidade entre grafite e poder público, mas mostrou-se agora mais assertivo: "Já vivi conflitos com isso, mas é um movimento natural. Hoje são poucas as pessoas com uma postura radical. E cresceu um movimento muito forte de um grafite estético". Enormes painéis ou murais de grafite vão sendo produzidos em favelas valorizando os aspectos estéticos, turísticos e culturais dessas localidades. Assim, foi inaugurado um museu a céu aberto no Morro do Cantagalo, em Copacabana, o MUF - Museu de Favelas, com obras de Acme, e o Caminho de Grafite, uma cobertura com grafite de 50 casas no morro dos Prazeres, em Santa Teresa. (Vital, 2014: 15)

Tal política pública de financiamento da produção de grafites foi pontual e, pelo que pudemos perceber a partir dos acontecimentos no Complexo do Alemão, não se estabeleceu de fato como uma política pública para toda a cidade. O grafite seguiu marginalizado e pouco reconhecido como arte, sendo parte de uma cultura de sobrevivência que marca a produção cultural em favelas e periferias urbanas brasileiras.

Em uma entrevista concedida a mim e a meus bolsistas de iniciação científica em 2012, um jovem artista do Complexo do Alemão, MC Calazans, utilizou a categoria "cultura de sobrevivência" para explicar uma experiência compartilhada por moradores de favelas. Ela se refere à vida em escassez de direitos e em ameaça permanente, a partir da qual são inventadas maneiras de se driblar a morte e criar sentidos de existência. No seu entender, só é possível compreender a arte criada nesse contexto reconstruindo a rede de relações necessárias à sobrevivência na favela. A minha pergunta era "O que havia de cultura e arte aqui no Alemão antes da chegada das UPPs?" Minha intenção era que ele confrontasse a narrativa que predominava nos meios de comunicação naquele período e que apresentavam o Complexo do Alemão como território desprovido de cultura, cuja salvação viria com a pacificação. Eu imaginava que sua resposta seria um inventário de produções artísticas, eventos culturais, agentes e grupos com atuação em arte e cultura na localidade. Mas ele me surpreendeu, me lembrando das belezas contidas nos imprevistos da pesquisa de campo. Suas palavras, que não pude compreender completamente então, inspiraram reflexões que me acompanham desde aquele momento:

Não existiria o Complexo do Alemão se não fosse a cultura. E a cultura não só a cultura artística do grafite, do rap, do pagode, do samba. Não, eu acho que é uma cultura da sobrevivência. Por exemplo, o gatonet. O gatonet nada mais é do que uma cultura de universalizar o acesso à internet. $\mathrm{O}$ gato luz nada mais é do que uma cultura da sobrevivência para universalizar o acesso à luz. Cultura da favela, do Complexo do Alemão principalmente, ela sempre veio da solidariedade. Então é assim: se você que mora embaixo do morro tem uma internet, o cara que mora aqui no pico da Grota tem que ter. Então pega os fiozinhos, vai engatando até chegar lá. Se você mora no pé do morro e tem 
saneamento básico, mano, puxa um caninho lá da puta que o pariu e vem emendando, fazendo gato, passando perrengue. Então essa cultura, que é o que acho mais importante, foda, incrível, essa cultura da sobrevivência fundada numa solidariedade, uma identidade de irmandade mesmo, que eu acho assim que é a mais... que poucas pessoas valorizam isso e quando valorizam é para legalizar: "vamo botar TV por assinatura, vamos acabar com os gatonets..." Quando isso é uma cultura que o morro criou. Lan houses, né, que foram criadas na própria favela para dar acesso à internet, mototáxi... Então a primeira cultura que a gente tem é uma cultura da sobrevivência. A gente tem uma realidade difícil, então, como vamos superar ela? Uma das formas de superar é construir uma cultura local. Fora isso, a parte mais tradicional da cultura, isso daqui, cara, é um celeiro de artistas. Artistas tanto do grafite, do pagode, do samba. Você tem a quadra da Imperatriz aqui na Pedra do Sapo, lá do início - isso eu sei por causa que os meus avós iam, foram uns dos fundadores de lá - e era o encontro dos neguinhos com cachaça e violão, fazendo música, fazendo samba. Não tinha luz no Complexo do Alemão, era tudo roça. Aí começou dali. Cada beco daqui tem uma certa identidade. ${ }^{11}$

Assim, mais do que expressões artísticas específicas, a cultura envolveria modos de vida permeados de solidariedade e de táticas para garantir direitos e acesso aos benefícios da modernidade, como luz elétrica, água encanada, internet e TV a cabo. A criação artística não pode ser separada dessa totalidade, pois ela é gerada pelos mesmos valores e elabora simbolicamente práticas cotidianas do chão dos becos que se tornam matéria-prima da criatividade. Segundo o MC, é desse ponto de partida que se pode compreender o grafite, o samba, o funk etc.

Sua formulação é muito próxima a de Homi Bhabha, intelectual indiano que se dedicou a pensar cultura e pós-colonialismo. Vejamos o que diz Bhabha:

\begin{abstract}
Nesse sentido salutar, toda uma gama de teorias críticas contemporâneas sugere que é com aqueles que sofreram o sentenciamento da história subjugação, dominação, diáspora, deslocamento - que aprendemos nossas lições mais duradouras de vida e pensamento. Há mesmo uma convicção crescente de que a experiência afetiva da marginalidade social - como ela emerge em formas culturais não-canônicas - transforma nossas estratégias críticas. Ela nos força a encarar o conceito de cultura exteriormente aos objets d'art ou para além da canonização da "ideia" de estética, a lidar com a cultura como produção irregular e incompleta de sentido e valor, frequentemente composta de demandas e práticas incomensuráveis, produzidas no ato da sobrevivência social. A cultura se adianta para criar uma textualidade simbólica, para dar ao cotidiano alienante uma aura de individualidade, uma promessa de prazer. A transmissão de culturas de sobrevivência não ocorre no organizado musée imaginaire das culturas nacionais com seus apelos pela continuidade de um "passado" autêntico e um "presente" vivo - seja essa escala de valor preservada nas tradições "nacionais" organicistas do romantismo ou dentro das proporções mais universais do classicismo. (Bhabbha, 1998: 240-241)
\end{abstract}

\footnotetext{
${ }^{11}$ Entrevista realizada em 12 de novembro de 2012, no Complexo do Alemão.
} 
Abordando a parte mais sensível e extrema do que MC Calazans e Homi Bhabha denominaram culturas de sobrevivência, Tássia Mendonça etnografa o cotidiano da favela do Batan, zona oeste do Rio de Janeiro, e acompanha a trajetória de uma moradora que perdeu dois filhos assassinados. A autora utiliza a expressão de uma de suas interlocutoras da pesquisa, "campo minado", para manifestar a ideia de viver no risco e ter a necessidade de aprender a sobreviver. Em poucos anos, o Batan conviveu com a presença do comércio varejista de substâncias ilícitas ("tráfico", em termos nativos), foi "tomada" por milicianos e, por fim, recebeu uma UPP ${ }^{12}$, a única implementada em região dominada por milícia. A mãe, apesar da dor, seguiu sua vida, trabalhando, se divertindo, namorando, resumindo essa superação nos termos "voltar a viver". Para analisar esse impulso de vida, Tássia se baseia em Primo Levi para definir os sobreviventes como aqueles que "chegaram perto do fundo, mas não o tocaram, não submergiram." A autora explica o recurso à obra de Primo Levi para compreender essa experiência comum entre moradores de favelas e periferias:

\begin{abstract}
Me volto para a obra de Primo Levi, especificamente em seu livro "Afogados e Sobreviventes". Em sua reflexão sobre o holocausto, o autor busca qualificar os meandres da sobrevivência, de que forma se sobrevive ao horror dos campos de concentração, e como lá mesmo já se instaurava uma diferença entre os que submergiam e aqueles que uma vez adaptados conseguiram se manter no limiar entre a vida e a morte. (...) Ao analisar a experiência de Cássia através da noção de sobrevivência não quero com isso colar a produção das mortes nas favelas cariocas com o que ocorreu nos campos de concentração alemães, mas antes pensar a noção de sobrevivência de uma forma alargada, como a capacidade mesma de passar por entre poderes que encurralam e oprimem, sem ver o aquilo que Primo Levi chama de "seu fundo", sua morte. (Mendonça, 2014: 52-3)
\end{abstract}

O voltar a viver de Cássia é associado a viver o hoje, se divertir e também a dar conta dos afazeres envolvidos no cuidado com a filha, com a casa e no trabalho, da vida imediata. Esse viver no imediato como tática do sobreviver também aparece nas falas das interlocutoras da dissertação de mestrado de Anna Massoz, que trata de trajetórias

\footnotetext{
${ }^{12}$ A experiência das UPPs iniciou-se no Rio de Janeiro com a instalação, em 2008, da primeira unidade no Morro Santa Marta, em Botafogo. As UPPs diferiam da abordagem tradicional da polícia nas favelas uma vez que, pelo menos em tese, substituem-se as incursões esporádicas e violentas por unidades permanentes de policiamento. De acordo com Rodrigues \& Siqueira (2012), esse modelo de policiamento não chegava a ser uma política de segurança. Era, ao contrário, um "experimento" ou uma "série de práticas policiais" cuja compreensão demanda um olhar para a prática e não apenas para os documentos e discursos oficiais das UPPs. Um dado do caráter experimental das UPPs: a lei que regula as unidades (decreto público 42.787 de 6 de Janeiro de 2011) foi promulgada apenas três anos após a implantação da primeira unidade. Em 2020 as UPPs se encontram desarticuladas e as incursões policiais em favelas voltaram a ser a face mais visível da política de segurança na cidade.
} 
de mulheres num curso preparatório para pós-graduação numa favela do Rio de Janeiro. Essas mulheres trabalhadoras, moradoras de favelas e periferias cariocas, conciliam o sonho de continuar os estudos em nível de pós-graudação com uma rotina dura de afazeres voltados para garantir sua sobrevivência e de suas famílias. Anna Massoz denomina isso de "imobilidade do instantâneo", que encerra desejos e aspirações de vida num "presente contínuo". Uma delas, Leonora, resume a questão:

\footnotetext{
Essa coisa do imediato, de ter que dar conta, ter que sobreviver, acaba, de certa forma, te atrapalhando, e você acaba se deixando levar e acaba não priorizando outras coisas. Tudo te leva para você, tipo: "Tô cansada, hoje, vou farrear, vou fazer tudo, menos estudar", a rotina, o cotidiano te levam pra isso mesmo. E aí você se deixa levar. (Apud Massoz, 2013: 122)
}

Essa ideia do deixar-se levar como o segredo para sobreviver é tematizado num samba muito popular cantado por Zeca Pagodinho e cuja letra transcrevo abaixo. É comum ouvir em rodas de samba e outros espaços de lazer da cidade do Rio de Janeiro que este samba é uma filosofia de vida, receita do bem viver das classes populares. A composição é de Serginho Meriti e Eri do Cais e seu título é Deixa a vida me levar:

\footnotetext{
Eu já passei por quase tudo nessa vida

Em matéria de guarida

Espero ainda a minha vez

Confesso que sou de origem pobre

Mas meu coração é nobre

Foi assim que Deus me fez

E deixa a vida me levar (vida leva eu!)

Deixa a vida me levar (vida leva eu!)

Deixa a vida me levar (vida leva eu!)

Sou feliz e agradeço

Por tudo que Deus me deu

Só posso levantar as mãos pro céu

Agradecer e ser fiel

Ao destino que Deus me deu

Se não tenho tudo que preciso

Com o que tenho, vivo

De mansinho lá vou eu

Se a coisa não sai do jeito que eu quero

Também não me desespero

O negócio é deixar rolar

E aos trancos e barrancos, lá vou eu!

E sou feliz e agradeço

Por tudo que Deus me deu

Deixa a vida me levar (vida leva eu!)
} 
O mesmo sentido de urgência da vida no tempo do agora, sem muito apego a planos de futuro, festejando o momento presente aparece num funk proibidão muito famoso, composto por Praga e gravado por MC Smith. Vida Bandida estourou nos bailes de favelas em 2009 e diz em seu refrão: "Hoje somos festa, amanhã seremos luto." Se esta frase é verdadeira, ainda mais para quem vive a vida bandida, o mundo do crime, o que importa é festejar e ser feliz com o que se tem hoje: a certeza de se estar vivo. Podemos afirmar que esse tema, comum às duas músicas, é recorrente na música popular brasileira em suas variadas vertentes.

Em contexto histórico e social bastante diverso, mas que podemos relacionar a experiências comuns às classes trabalhadoras no mundo contemporâneo, Richard Hoggart, em seu trabalho clássico sobre os hábitos de leitura da classe trabalhadora britânica no Pós-Guerra, reflete sobre esse modo de vida construído a partir da escassez e das dificuldades cotidianas para garantir a sobrevivência. Intelectual oriundo da classe trabalhadora, ele mistura em suas análises observação participante e vivências próprias de sua classe, tratando das estratégias para "aguentar" desenvolvidas pelos pobres. Nas suas palavras,

\footnotetext{
Quando as pessoas se dão conta de que não podem modificar os principais dados da situação em que se encontram, e nem por isso se sentem desesperadas, desapontadas ou sequer ressentidas, aceitando essa imutabilidade como uma coisa natural, adotam em relação a uma tal situação atitudes que lhes permitem viver nessas circunstâncias, sem se lembrarem demasiado da situação em geral e seus inconvenientes. Essas atitudes tendem a transformar os principais elementos da situação em leis naturais, na matériaprima imutável da vida. Reduzindo-se geralmente a uma simples aceitação, ou a um aceitação fatalista das coisas tal como elas são, essas atitudes não se alçam nunca a um nível trágico; de resto, não pode haver tragédia, porque não há escolha. Revestem-se no entanto de uma certa dignidade, pelo menos nalgumas das formas que assumem. (Hoggart, 1973:111)
}

Sem menosprezar as diferenças históricas significativas, é preciso reconhecer que há experiências de classe que são compartilhadas sob o capitalismo, manifestas em táticas comuns de enfrentamento à precariedade e à marginalização. Das e Poole chamam essas táticas de criatividade das margens, forjadas na necessidade de sobrevivência. Para as autoras, as margens não são somente espaços períféricos, mas sim locais onde o Estado é permanentemente reconfigurado nos processos cotidianos. Se, por um lado, são espaços de exceção onde são produzidos corpos matáveis, por outro são também locais de reconfiguração conflituosa desse mesmo Estado, marcada 
por resistências, mas sobretudo por rearranjos e reacomodações permanentes. Em suas palavras,

Paradoxically, these spaces of exception are also those in which the creativity of the margins is visible, as alternative forms of economic and political action are instituted. To suggest that margins are spaces of creativity is not to say that forms of politics and economics on the margins, often fashioned out of the need to survive, are not fraught with terrible dangers. It is, however, to draw attention to the fact that though certain populations are pathologized through various kinds of power/knowledge practices, they do not submit to these conditions passively. (Das e Poole, 2004: 19)

No entanto, ao invés de enfatizar as resistências em momentos críticos, elas focam a análise na vida cotidiana, em processos nos quais as fronteiras conceituais do Estado são estendidas e refeitas nas lutas por justiça ou por assegurar sobrevivência. Se elas se concentram em criatividades políticas e econômicas nessa busca de sobreviver, podemos pensar em direção semelhante no que diz respeito à criação artística. Retorno aqui à fala do MC Calazans:

\begin{abstract}
A arte não sai do nada, ela precisa ser provocada. Aqui na favela ela é provocada por uma série de razões. A mais forte que eu vejo é a razão de dar traços artísticos a uma realidade que é muito dura, de sobrevivência mesmo. $\mathrm{Eu}$ acho assim, na favela a gente tem muito claro que viver e morrer é uma linha tênue que separa as coisas. (..) Viver e morrer aqui é muito... sabe? É o tempo inteiro esse confrontamento. Como que eu vou inventar arte do nada vivendo nisso? Como que a minha arte vai sair de uma abstração que eu tive vendo a favela da Grota, o teleférico e aí do nada sai? Impossível, impossível. Eu não consigo entender uma parada dessas. ${ }^{13}$
\end{abstract}

Entre viver e morrer. Esse o estado da sobrevivência, do perigo de que falam Das e Poole. É a partir desse lugar que a arte é criada. Em uma música que se tornou símbolo das violações de direitos que as UPPs representavam para movimentos sociais surgidos em favelas no Rio de Janeiro, o MC articula essa experiência de liminaridade em forma de poesia:

Paz sem voz não é paz, é medo

Paz sem voz não é paz, é gueto

Favelado merece respeito

Não tapa na cara e porrada nos peito

A gente não quer só polícia

A gente quer comida, diversão e arte

A gente não quer só polícia

A gente quer comida, diversão e liberdade

${ }^{13}$ Entrevista realizada em 12 de novembro de 2012, no Complexo do Alemão. 
Cadê o baile? Baile acabo!

E us morador? Tapa levo

É os homi...de 12 na mão

Se questionar...vai pro camburão

Policia passa e fica a dor

Policia passa e deixa dor

Policia Passa e fica a dor

Hoje no complexo um neguin chorou

Pois seu pai, foi e não voltou

A mãe tá triste e orou ao senhor:

A policia passou, mas a dor ficou

Cantar funk, é uma oração

Prá que a paz não venha de caveirão

Que sobre isso, não venha mais cantar

Favela de dor, mas não pára de criar

A arte criada a partir da cultura de sobrevivência acaba tensionando o próprio conceito de arte, em analogia ao que ocorre com o Estado em suas margens conforme argumentamos acima. Se o Estado se reconfigura em suas margens, podemos dizer que a arte também. Tanto na fala do MC, quando se recusa a produzir arte "do nada", quanto em sua música, quando expressa o desejo de "que sobre isso não venha mais cantar" e quando opõe "dor" a "criar", a criação artística é ao mesmo tempo finalidade sem fím kantiana e ferramenta de intervenção no mundo, de uso prático para a transformação da realidade. E a força do uso é tamanha que o cantar funk é ação apresentada como oração que, ao criar música, pode gerar, com sua eficácia simbólica e material, uma realidade na qual "a paz não venha de caveirão”. Assim, se por um lado há, no plano do desejo, o compartilhamento de uma ótica hegemônica do campo artístico contemporâneo nos termos de Pierre Bourdieu ${ }^{14}$, cuja representação máxima de autonomização é a afirmação da "arte pela arte", por outro existe a urgência da arte como uso e intervenção, cujo teste de validade é a intenção de transformar essa realidade. A arte "do nada" fica como horizonte para um mundo a conquistar, para um devir no qual a luta pela sobrevivência não seja mais necessária, no qual haja "comida, diversão e

\footnotetext{
${ }^{14} \mathrm{Em}$ As regras da arte, Bourdieu afirma que o campo artítistico se constitui na contemporaneidade de modo a conferir a função de distinção à criação e à fruição estéticas. À aristocracia de sangue, marcada pela herança familiar, se substitui a aristocracia do gosto, cujo habitus a distingue das camadas socialmente inferiores. Para cumprir tal função, a arte necessita ser vista como algo autônomo, nas quais questões políticas e econômicas são denegadas em nome da livre criação e da expressão plena do gênio do artista criador. (Bourdieu, 1996)
} 
liberdade." No instante presente, o que há é dor cotidiana e a necessidade de transmutála em criação estética, com o objetivo de mudar (ou afirmar a possibilidade de mudança) do estado de coisas que gera essa dor.

Assim, retornamos à escada grafitada por Mario Bands. O grafite é arte efêmera, pois é feita nas ruas, em suportes sempre passíveis de serem derrubados, repintados, remodelados. O que permanece é o registro fotográfico e também os compartilhamentos via rede social. Além disso, sobrevive nas reminiscências daqueles que viram pessoalmente a obra e fruíram a arte de corpo presente, a memória dos sentimentos despertados, os reconhecimentos e os estranhamentos que ela foi capaz de mobilizar. Mais uma vez, trata-se de um tensionamento da própria definição do que seria arte, debate que sempre se atualiza quando o assunto é esse tipo de arte urbana. Que pensar então de uma arte efêmera realizada num ambiente no qual remoção é signo sempre disponível a indicar a provisoriedade da vida? Se um escombro de uma remoção parecia durar infinitamente como "símbolo do descaso", lembrando a casa destruída e os moradores dali desenraizados, sua transformação em arte ressignificou o sentido do provisório e marcou o que permanece, o que sobrevive. A "escada da memória", nos termos de moradores do Complexo do Alemão.

Em outubro de 2014, postei no Facebook um vídeo em que palestrava sobre o tema e pus o título "A escada de Mario Bands". Logo em seguida, o artista deixou um comentário elucidativo para a discussão que desenvolvemos aqui:

\footnotetext{
A Escada não é minha não! (Rsrs) Foi de algum morador e se tornou pública aos olhos de alguns expectadores (pois teve vida curta), e simboliza o descaso, o abandono... O que fiz foi me apropriar dos escombros com minha intervenção, e torna-lá Arte. E trazer a mesma questão para outro campo de discussão.
}

Apropriação de escombros transformados em Arte com A maiúsculo, simbolizando um problema cotidiano trazido para "outro campo de discussão" por meio de uma criação estética. Como na música do MC Calazans, é a dor como matéria criativa e como elemento que legitima a arte como intervenção, como utilidade, tornando fluidas as fronteiras entre criar e fruir, entre criar e intervir, entre fruir e se manifestar politicamente. Restaram da escada os fragmentos, recolhidos por Helcimar Lopes na urgência da sua demolição e reconstruída em monumento à memória da escada da memória na entrada da sede do Instituto Raízes em Movimento. Metáfora inscrita na parede a lembrar mortes e sobrevivências a perdurar no tempo. 
Adriana Facina
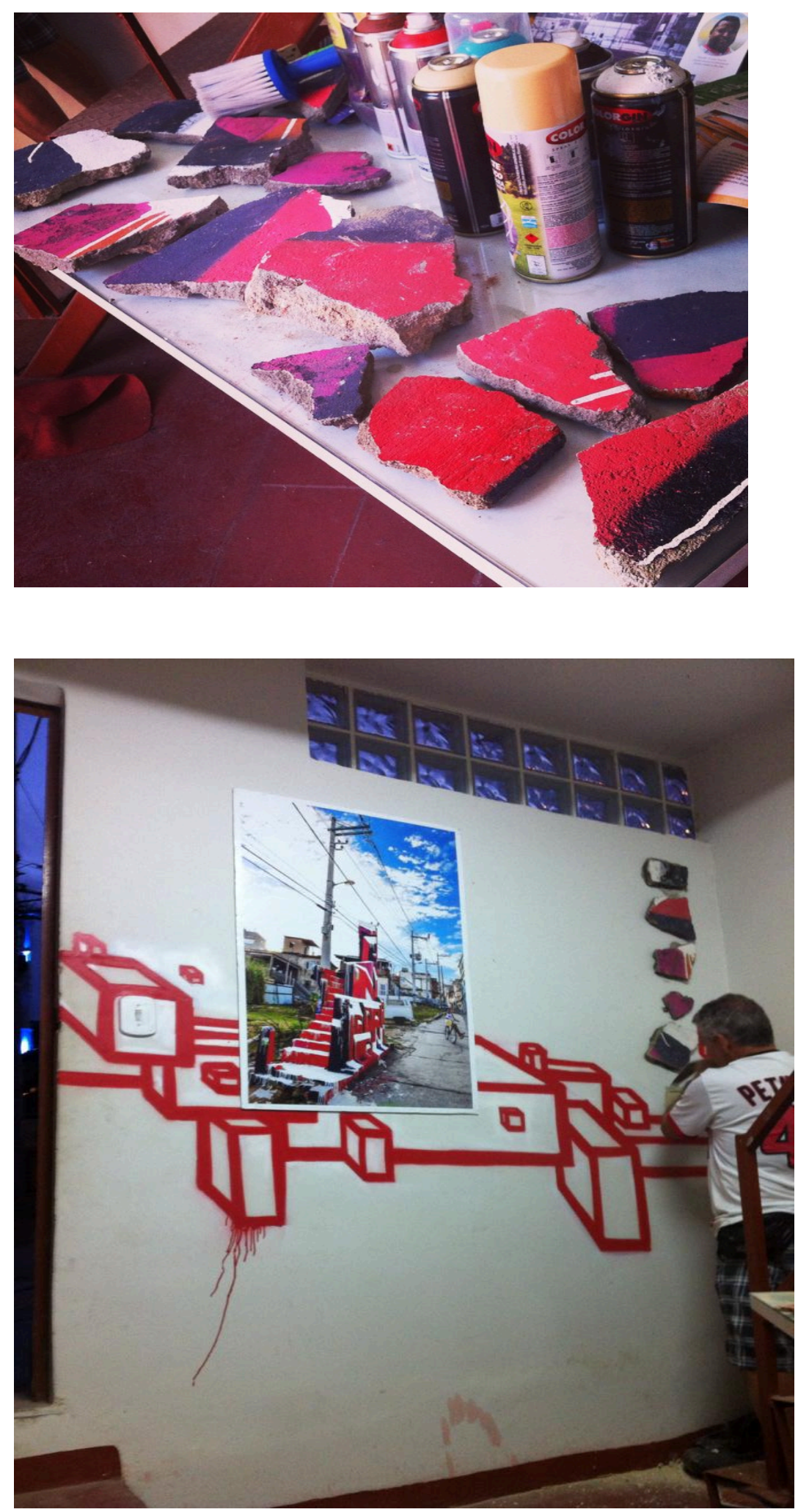

Em permanente ameaça e frequentemente destruídas, as manifestações culturais produzidas no contexto da cultura de sobrevivência são obrigadas a inventar as formas 
de sua permanência. Como um rio que muda, mas permanece o mesmo em seu fluxo constante, assim as culturas de sobrevivência que caracterizam as favelas e periferias dependem de criatividade e persistência, de uma continuidade resistente. Mas essa cultura tem limites para sua eficácia e para sua perpetuação. De acordo com MC Calazans, esse limite é o do extermínio, gestão última e radical de corpos que deixa pelo caminho dezenas de milhares de assassinados no Brasil a cada ano. Segundo o Atlas da Violência do IPEA publicado em 2019, foram 65.602 homicídios no Brasil em 2017. Mais da metade das vítimas são jovens de 15 a 29 anos, $75,5 \%$ são negros. ${ }^{15}$ Como matáveis prioritários, os jovens, negros e favelados. A consciência de viver permanentemente em risco de vida tem como drama a "arma apontada para a cara", experiência comum entre jovens de periferias. Um artista que entrevistei contou-me que, ao abordar um jovem da favela que tinha "entrado para o tráfico", com o objetivo de trazê-lo de volta ao grupo de dança ao qual pertencia, ouviu a pergunta que resume numa frase esse drama: "Você quer que eu morra atirando ou dançando?". Pouco depois, o rapaz que lançou a pergunta no ar morreu assassinado durante uma operação policial. Quando a morte é certa, a luta pela sobrevivência se esvazia de sentido, não há nada que se possa fazer. O fluxo das culturas de sobrevivência, ainda que acossado pelo imediato, escava caminhos de esperança em pedra dura. Interrompido este fluxo, o que resta é agora.

\section{REFERÊNCIAS}

BATISTA, Vera Malaguti. "O Alemão é muito mais complexo". Texto apresentado no $17^{\circ}$ Seminário Internacional de Ciências Criminais em São Paulo, 23/07/2011.

BHABBA, Homi K. O local da cultura. Belo Horizonte, Ed.UFMG, 1998.

BOURDIEU, Pierre. As regras da arte. São Paulo, Companhia das Letras, 1996.

CERTEAU, Michel de. A cultura no plural. Campinas, Papirus, 1995. . A invenção do cotidiano. 1. Artes de fazer. Petrópolis, Vozes, 2012.

\footnotetext{
${ }^{15}$ O Atlas da Violência 2019 pode ser baixado em: https://www.ipea.gov.br/atlasviolencia/
} 
DAS, Veena e POOLE, Deborah (ed.). Anthropology in theMargins of the State. New Mexico, School of American Research Press, 2004.

FACINA, Adriana. Sobreviver e sonhar: reflexões sobre cultura e "pacificação" no Complexo do Alemão. In: PEDRINHA, Roberta Duboc e FERNANDES, Márcia Adriana (org.). Escritos transdisciplinares de criminologia, direito e processo penal: homenagem aos mestres Vera Malaguti e Nilo Batista. Rio de Janeiro, Revan, 2014. p. $39-48$.

HOOGART, Richard. As utilizações da cultura. Aspectos da vida cultural da classe trabalhadora, com especiais referências a publicações e divertimentos. Lisboa, Presença, 1973. 2 volumes.

LOPES, Adriana C.; FACINA, Adriana; SILVA, Daniel N. (orgs.). Nó em pingo d'água. Sobrevivência, cultura e linguagem. Rio de Janeiro/Florianópolis, Mórula/Insular, 2019.

MASSOZ, Anna Marianne Jean-Pierre Natacha. Trajetórias e aspirações de mulheres estudantes de um curso preparatório para a pós-graduação em uma comunidade da periferia do RJ. Rio de Janeiro, UFRJ, 2014. (dissertação de mestrado)

MENDONÇA, Tássia. Batan: Tráfico, Milícia e "Pacificação" na Zona Oeste do Rio de Janeiro.Rio de Janeiro, UFRJ 2014. (dissertação de mestrado) .

OLIVEIRA, Bruno Coutinho de Souza. "Não tem essa de separação, aqui é tudo Complexo do Alemão!”: uma etnografia dos espaços urbanos em um conjunto residencial no Rio de Janeiro. Universidade do Estado do Rio de Janeiro, Instituto de Estudos Sociais e Políticos, 2018. (tese de doutorado).

VALLA, Victor Vincent. Educação e favela. Petrópolis, Vozes/ABRASCO, 1986.

VITAL, Christina. Religião, grafite e projetos de cidade: embates entre "cristianismo da batalha" e "cristianismo motivacional" na arte efêmera urbana. Ponto.Urbe (USP), v. 15, 2014. p. $1-21$.

. Grafites do amor, da paz e da alegria na cidade Olímpica: interfaces entre política, arte e religião no Rio 2016. Revista Ciências Sociais Unisinos, v. 3, 2017. p. 499-507.

Recebido: $23 / 06 / 2020$

Aprovado: 04/09/2020 